\title{
Evaluasi Sistem Pengelolaan Limbah Medis dan Zat Berbahaya di
} Rumah Sakit XXX

\author{
Muflikun', \\ ${ }^{1}$ Magister Manajemen Rumah Sakit, Universitas Muhammadiyah Yogyakarta \\ Email: muflikn@gmail.com \\ Kampus Terpadu UMY JI. Brawijaya, Kasihan, Bantul Yogyakarta 55183
}

\begin{abstract}
Abstrak
Rumah Sakit adalah institusi pelayanan kesehatan yang berpotensi menghasilkan limbah cukup banyak. Limbah rumah sakit mencakup semua buangan yang berasal dari kegiatan rumah sakit dalam bentuk padat, cair, pasta (gel) maupun gas yang mengandung mikroorganisme, bahan kimia beracun, dan bersifat radio aktif. Pengelolaan limbah di setiap rumah sakit mengacu pada Kemenkes RI No.1204/Menkes/SK/X/2004. Pengelolaan dimulai sejak pemilahan, pengangkutan dan pemusnahan. Untuk mengevaluasi sistem pengolahan sampah dan bahan berbahaya di rumah sakit XXX. Penelitian ini kuantitatif dengan pendekatan observasi. Populasi yang digunakan dalam penelitian ini yaitu pimpinan dan seluruh petugas pengelola sampah. Sampel penelitian ini ialah seluruh populasi yang mempunyai peran dalam pengelolaan sampah. Analisis yang digunakan adalah data hasil dari wawacara dan checklist hasil observasi. Pelaksanaan prosedur pengolahan limbah sebagian besar sudah dilakukan semua. Pada tahap pemilihan, pengumpulan, pengangkutan dan penyimpanan limbah medis benda tajam, pengolahan dan pemusnahan, pencatatan dan pelaporan masih ada beberpa syarat yang belum terlaksana. Pelengkapan dokumen pengolahan limbah diketahui sudah ada semua dan tersedia dengan lengkap. Analisa pengelolaan sampah diketahui sebagian besar sudah terlaksana. Namun pada indikatror sarana prasarana, petugas kebersihan, perlakuan terhadap limbah dan tanda peringatan sebagian besar belum dilakukan secara menyeluruh. Pelaksanaan prosedur pengolahan limbah dan pengelolaan sampah di rumah sakit XXX belum sesuai dengan Persyaratan Kesehatan Lingkungan Rumah Sakit dan Pengelolaan Limbah Bahan Berbahaya dan Beracun (B3). Kelengkapan dokumen pengolahan limbah medis ada dan sudah tersedia dengan lengkap.
\end{abstract}

Kata kunci: Sistem Pengolahan Limbah dan Zat Berbahaya

\section{Evaluation of Medical Waste Management System and Hazardous Substance at XXX Hospital}

\section{Abstract}

Hospitals are health care institutions that have the potential to generate enough waste. Hospital waste covers all discharges derived from hospital activities in solid, liquid, paste (gel) or gases containing microorganisms, toxic chemicals, and radioactive properties. Waste management in each hospital refers to the Ministry of Health RI No.1204/Menkes/SK/X/2004. Management starts from sorting, transport and destruction. To evaluate the system of processing waste and hazardous materials at $X X X$ hospital. This research is quantitative with observation approach. The population used in this research is the leader and all garbage management officers. The sample of this study is the entire population that has a role in waste management. The analysis used is data result from wawacara and checklist of observas result. Implementation of waste treatment procedures are mostly done all. At the election stage, the collection, transportation and storage of sharps medical waste, processing and destruction, recording and reporting still have some unfulfilled requirements. Document preparation of waste treatment is known to have all and is available completely. Analysis of waste management is known to have been largely accomplished. However, in indicator means of infrastructure, cleaning officers, treatment of waste and warning signs have not been done thoroughly. Implementation of waste treatment procedures at XXX Hospital is not in accordance with regarding Hospital Health Environment Requirements and criteria of Waste Management of Hazardous and Toxic Substances (B3). The completeness of the medical waste processing document exists and is fully available.

Keywords: Wastewater Treatment System and Hazardous Substance

Received: 15/04/2018; published: 28/05/2018 


\section{PENDAHULUAN}

Menurut Peraturan Menteri Kesehatan Republik Indonesia Nomor: 1045/Menkes/PER/XI/2006, Rumah Sakit adalah suatu fasilitas pelayanan kesehatan perorangan yang menyediakan rawat inap dan rawat jalan yang memberikan pelayanan kesehatan jangka pendek dan jangka panjang yang terdiri dari observasi, diagnostik, terapeutik dan rehabilitatif untuk orangorang yang menderita sakit, cidera dan melahirkan.

Rumah Sakit merupakan penghasil sampah yang cukup banyak setiap harinya dan seringkali bersifat toksik, terutama sampah padat, baik itu sampah medis maupun sampah non medis. Pengolahan sampah diatur dalam undang-undang yaitu UU no 32 tahun 2009 tentang perlindungan dan pengelolaan sampah $(1,2)$.

Hasil kajian yang dilakukan Arifin (2008) terhadap 100 rumah sakit di Jawa dan Bali menunjukan rata rata produksi sampah sebesar 3,2 kg/tempat tidur/hari. Analis lebih jauh menunjukan, produksi sampah berupa sampah domestic sebesar $76,8 \%$ dan berupa sampah infeksius sebesar 23,2\%. Diperkirakan secara nasional produksi sampah rumah sakit sebesar 376.089 ton per hari (3). Dari gambaran tersebut dapat dibayangkan betapa besar potensi rumah sakit untuk mencemari lingkungan dan kemungkinannya menimbulkan kecelakaan serta penularan penyakit. Karakteristik sampah medis memiliki sifat infeksius atau toksik, jika tidak dikelola dengan tepat, akan menyebabkan pencemaran.

Menurut KEPMENKES RI nomor 1204 tahun 2004 limbah padat rumah sakit adalah semua limbah rumah sakit yang berbentuk padat akibat kegiatan rumah sakit yang terdiri dari limbah medis padat dan non medis. Limbah non medis adalah limbah padat yang dihasilkan dari kegiatan di luar medis yang berasal dari dapur, perkantoran, taman dan halaman yang dapat dimanfaatkan kembali apabila ada teknologi. Limbah non medis ini penyimpanannya pada tempat sampah berplastik hitam. Sedangkan Limbah medis padat adalah limbah padat yang terdiri dari limbah infeksius dan limbah patologi, limbah farmasi (obat kadaluarsa), limbah sitotoksis adalah limbah berasal dari sisa obat pelayanan kemoterapi, limbah medis padat tajam seperti pecahan gelas, jarum suntik, pipet dan alat medis lainnya serta limbah radioaktif adalah limbah berasal dari penggunaan medis ataupun riset di laboratorium yang berkaitan dengan zatzat radioaktif (4).

Salah satu kegitan rumah sakit adalah sanitasi rumah sakit dimana salah satu upaya yang dilakukan rumah sakit dalam rangka pelayanan sanitasi rumah sakit adalah pengelolaan sampah. Pengelolaan sampah merupakan salah satu aspek strategis dari rumah sakit, karena dengan pengelolaan sampah yang baik akan menciptakan image yang baik bagi rumah sakit (5).

Unit sanitasi rumah sakit sebagai bagian dari organisasi rumah sakit dalam melaksanakan fungsi organisasinya mengikut alur atau mekanisme yang disebut suatu system yang meliputi input, proses dan output. Demikian halnya dengan pengelolaan sampah di rumah sakit XXX berupa input yang meliputi perencanaan pengelolan sampah, proses yang 
meliputi pelaksanaan pengelolaan sampah, proses yang meliputi pelaksanaan pengelolaan sampah, dan output yang meliputi hasil pengelolaan sampah.

Pihak rumah sakit $X X X$ telah melaksanakan pengelolaan sampah, akan tetapi pengelolaan sampah yang dilakukan dirasakan belum optimal. Hasil studi pendahuluan pada bulan Januari 2016 di instalasi Sanitasi menunjukan bahwa ada beberapa masalah yang ditemukan salah satunya dari segi input belum dilakukan perencanaan Sumber Daya Manusia (SDM). Jumlah SDM yang menangani pengelolaan sampah baik medis maupun non medis terbatas sehingga mengakibatkan beban kerja pegawai yang menangani sampah menjadi bertambah. Dari 7 petugas pengelola sampah, ada 3 petugas yang mengalami kelebihan beban kerja.

Pengelolaan limbah di setiap rumah sakit sudah mengacu pada Kemenkes RI No.1204/Menkes/ SK/X/2004 tentang persyaratan kesehatan lingkungan Rumah Sakit. Pengelolaan ini dimulai sejak pemilahan, pengangkutan dan pemusnahan. RS XXX juga mempunyai unit sanitasi dan SOP pengolahan limbah sampah medis, sarana dan prasarana pengelolaan limbah dan dokumen kerjasama pemusnahan limbah dengan pihak ketiga yang berizin (4). Namun karena pengelolaan limbah ini melibatkan sumber daya manusia mulai dari proses pengumpulan sampai pemusnahan yang membutuhkan perilaku dan ketaatan dari sumber daya manusia tersebut, maka dari itu masih perlu dilakukan evaluasi dan pengawasan terus menerus terhadap pengelolaan limbah rumah sakit.

\section{BAHAN DAN METODE}

Penelitian ini deskriptif kuantitatif dengan pendekatan observasi (6). Populasi yang digunakan dalam penelitian ini yaitu pimpinan dan para petugas pengelola sampah. Sampel penelitian ini yaitu semua petugas yang mempunyai peran dalam pengelolaan sampah di rumah sakit XXX.

Pengumpulan data dilakukan dengan observasi, data sekunder dan wawancara. Analisis data menggunakan hasil wawacara diperkuat dengan checklist hasil observasi.

\section{HASIL DAN PEMBAHASAN}

Pelaksanaan Prosedur Pengolahan Limbah di RS XXX

Hasil checklist observasi pelaksaanaan prosedur pengolahan limbah di rumah sakit XXX dijabarkan sebagai berikut: 
Tabel 1 Pelaksanaan Prosedur Pengelolaan Limbah di rumah sakit XXX

\begin{tabular}{|c|c|c|c|c|}
\hline \multirow{3}{*}{ Tahap dan Syarat Prosedur Pengolahan Sampah } & \multicolumn{4}{|c|}{ Pelaksanaan } \\
\hline & \multicolumn{2}{|c|}{ Ya } & \multicolumn{2}{|c|}{ Tidak } \\
\hline & $\mathbf{n}$ & $\%$ & $\mathbf{n}$ & $\%$ \\
\hline \multicolumn{5}{|l|}{ Pemilihan } \\
\hline $\begin{array}{l}\text { Pemilahan limbah medis harus dilakukan mulai } \\
\text { dari sumber yang menghasilkan limbah. }\end{array}$ & 14 & 100 & 0 & 0 \\
\hline $\begin{array}{l}\text { Jarum dan syringes harus dipisahkan agar tidak } \\
\text { dapat digunakan kembali. }\end{array}$ & 14 & 100 & 0 & 0 \\
\hline $\begin{array}{l}\text { Jarum dihancurkan dengan alat pemotong jarum } \\
\text { atau pemusnah jarum supaya lebih aman dan } \\
\text { mengurangi resiko cidera. }\end{array}$ & 0 & 0 & 14 & 100 \\
\hline \multicolumn{5}{|l|}{ Pewadahan } \\
\hline $\begin{array}{l}\text { Limbah medis benda tajam dikumpulkan dalam } \\
\text { satu wadah tanpa memperhatikan itu } \\
\text { terkontaminasi atau tidak. }\end{array}$ & 14 & 100 & 0 & 0 \\
\hline $\begin{array}{l}\text { Wadah harus anti bocor, anti tusuk dan tidak } \\
\text { mudah di buka. }\end{array}$ & 14 & 100 & 0 & 0 \\
\hline $\begin{array}{l}\text { Wadah atau container diberi warna kuning dan } \\
\text { bertuliskan limah medis benda tajam. } \\
\text { Pemanfaatan kembali atau daur ulang }\end{array}$ & 14 & 100 & 0 & 0 \\
\hline $\begin{array}{l}\text { Limbah yang akan dimanfaatkan kembali harus } \\
\text { dipisahkan dari limbah yang tidak dimanfaatkan } \\
\text { kembali. }\end{array}$ & 14 & 100 & 0 & 0 \\
\hline $\begin{array}{l}\text { Limbah medis yang akan dimanfaatkan kembali } \\
\text { harus melalui proses sterilisasi }\end{array}$ & 14 & 100 & 0 & 0 \\
\hline $\begin{array}{l}\text { Limbah jarum hipodermik tidak disarankan untuk di } \\
\text { daur ulang. }\end{array}$ & 14 & 100 & 0 & 0 \\
\hline $\begin{array}{l}\text { Sterilisasi dilakukan secara kimiawi, dibakar atau } \\
\text { dengan autoclave. }\end{array}$ & 14 & 100 & 0 & 0 \\
\hline \multicolumn{5}{|l|}{$\begin{array}{l}\text { Pengumpulan, pengangkutan, dan penyimpanan } \\
\text { limbah medis benda tajam }\end{array}$} \\
\hline $\begin{array}{l}\text { Kantong limbah harus tertutup atau terkat kuat } \\
\text { apabila sudah penuh } 3 / 4 \text {. }\end{array}$ & 14 & 100 & 0 & 0 \\
\hline $\begin{array}{l}\text { Container limbah medis benda tajam sudah di } \\
\text { tutup dan dimasukkan dalam kantong plastik } \\
\text { kuning berlabel limbah infeksius. }\end{array}$ & 14 & 100 & 0 & 0 \\
\hline $\begin{array}{l}\text { Pengumpulan kantong dari tiap ruangan dilakukan } \\
\text { setiap hari dan diangkut menggunakan kereta atau } \\
\text { troli. }\end{array}$ & 14 & 100 & 0 & 0 \\
\hline $\begin{array}{l}\text { Alat angkut tidak memiliki sudut tajam yang dapat } \\
\text { merusak kantong dan aman dari tumpahan cairan. }\end{array}$ & 13 & $\begin{array}{l}92,8 \\
6\end{array}$ & 1 & 7,14 \\
\hline $\begin{array}{l}\text { Penyimpanan pada musim hujan maksimal } 48 \text { jam } \\
\text { dan musim kemarau } 24 \text { jam. }\end{array}$ & 0 & 0 & 14 & 100 \\
\hline $\begin{array}{l}\text { Petugas yang menangani limbah harus } \\
\text { menggunakan alat pelindung diri. }\end{array}$ & 13 & $\begin{array}{l}92,8 \\
6\end{array}$ & 1 & 7,14 \\
\hline \multicolumn{5}{|l|}{$\begin{array}{l}\text { Pengolahan dan pemusnahan limbah medis benda } \\
\text { tajam }\end{array}$} \\
\hline Limbah ditimbah dulu berdasarkan jenisnya. & 14 & 100 & 0 & 0 \\
\hline $\begin{array}{l}\text { Petugas melakukan dokumentasi dan pencatatan } \\
\text { limbah medis yang akan dimusnahkan. }\end{array}$ & 14 & 100 & 0 & 0 \\
\hline
\end{tabular}




\begin{tabular}{|c|c|c|c|c|}
\hline \multirow{3}{*}{ Tahap dan Syarat Prosedur Pengolahan Sampah } & \multicolumn{4}{|c|}{ Pelaksanaan } \\
\hline & \multicolumn{2}{|c|}{ Ya } & \multicolumn{2}{|c|}{ Tidak } \\
\hline & $\mathbf{n}$ & $\%$ & $\mathbf{n}$ & $\%$ \\
\hline $\begin{array}{l}\text { Limbah medis benda tajam harus diolah dengan } \\
\text { incinerator dengan suhu } 700^{\circ} \mathrm{C} \text {. }\end{array}$ & 14 & 100 & 0 & 0 \\
\hline $\begin{array}{l}\text { Petugas incinerator merupakan petugas yang } \\
\text { telah mendapatkan pelatihan khusus. }\end{array}$ & 2 & 14,2 & 12 & 85,7 \\
\hline \multicolumn{5}{|l|}{ Pembuangan akhir limbah medis benda tajam } \\
\hline $\begin{array}{l}\text { Limbah medis benda tajam yang infeksus dapat } \\
\text { diolah dahulu menggunakan encapsulation. }\end{array}$ & 0 & 0 & 14 & 100 \\
\hline $\begin{array}{l}\text { Setelah dinsenerasi limbah medis benda tajam } \\
\text { yang sudah tidak berbahava dapat dibuang ke } \\
\text { landfill. }\end{array}$ & 0 & 0 & 14 & 100 \\
\hline \multicolumn{5}{|l|}{ Pencatatan dan pelaporan } \\
\hline $\begin{array}{l}\text { Petugas metakukan pencatatan harian mengenai } \\
\text { limbah yang dihasilkan. }\end{array}$ & 12 & 85,7 & 2 & 14,2 \\
\hline $\begin{array}{l}\text { Petugas melakukan pencatatan insiden bagi } \\
\text { petugas yang mengalami kecelakaan, jenis } \\
\text { penyebab dan waktu serta pertolongan yang telah } \\
\text { diberikan. }\end{array}$ & 14 & 100 & 0 & 0 \\
\hline $\begin{array}{l}\text { Petugas mencatat jenis dan volume limbah yang } \\
\text { diangkut dan dimusnahkan. }\end{array}$ & 14 & 100 & 0 & 0 \\
\hline $\begin{array}{l}\text { Petugas melaporkan kepada pimpinan rumah sakit } \\
\text { dan pihak rumah sakit melaporkan kegiatan } \\
\text { pengelaan limbah kepada instansi terkait yaitu } \\
\text { Dinkes dan Bapedal. }\end{array}$ & 14 & 100 & 0 & 0 \\
\hline
\end{tabular}

Berdasarkan Tabel 1 tahap

pemilahan limbah medis sudah dilakukan

mulai dari sumber yang menghasilkan

limbah dan jarum dan syringes dipisahkan

agar tidak dapat digunakan kembali.

Namun pada proses penghajuran jarum

dengan alat pemotong atau pemusnah

jarum supaya lebih aman dan mengurangi

resiko cidera tidak dilakukan sebab sudah

di tangani pihak ketiga yang bertanggung

jawab. Tahap pewadahan dan pemanfaatan kembali diketahui sudah dilakukan semua, dan pada tahap pengumpulan, pengangkutan, dan penyimpanan limbah medis benda tajam sebagian besar juga sudah dilakukan, hanya tersedianya alat angkut yang tidak memiliki sudut tajam dan petugas yang menangani limbah harus menggunakan alat pelindung diri belum dilakukan secara maksimal $(98,26)$.

Pada tahap pengolahan dan pemusnahan limbah medis benda tajam diketahui sudah dilakukan semua, tetapi tidak semua petugas incinerator telah mendapatkan pelatihan khusus $(85,71 \%)$. Pada tahap pembuangan akhir limbah medis benda tajam diketahui tidak dilakukan semua. Sedangkan tahap dan syarat pencatatan dan pelaporan diketahui sudah dilakukan semua, kecuali petugas metakukan pencatatan harian mengenai limbah yang dihasilkan $(85,71 \%)$. 


\section{Kelengkapan Dokumen Pengolahan Limbah di Rumah Sakit XXX.}

Hasil checklist kelengkapan dokumen di rumah sakit XXX dijabarkan dalam tabel berikut:

Tabel 2 Kelengkapan Dokumen Pengelolaan Limbah di rumah sakit XXX

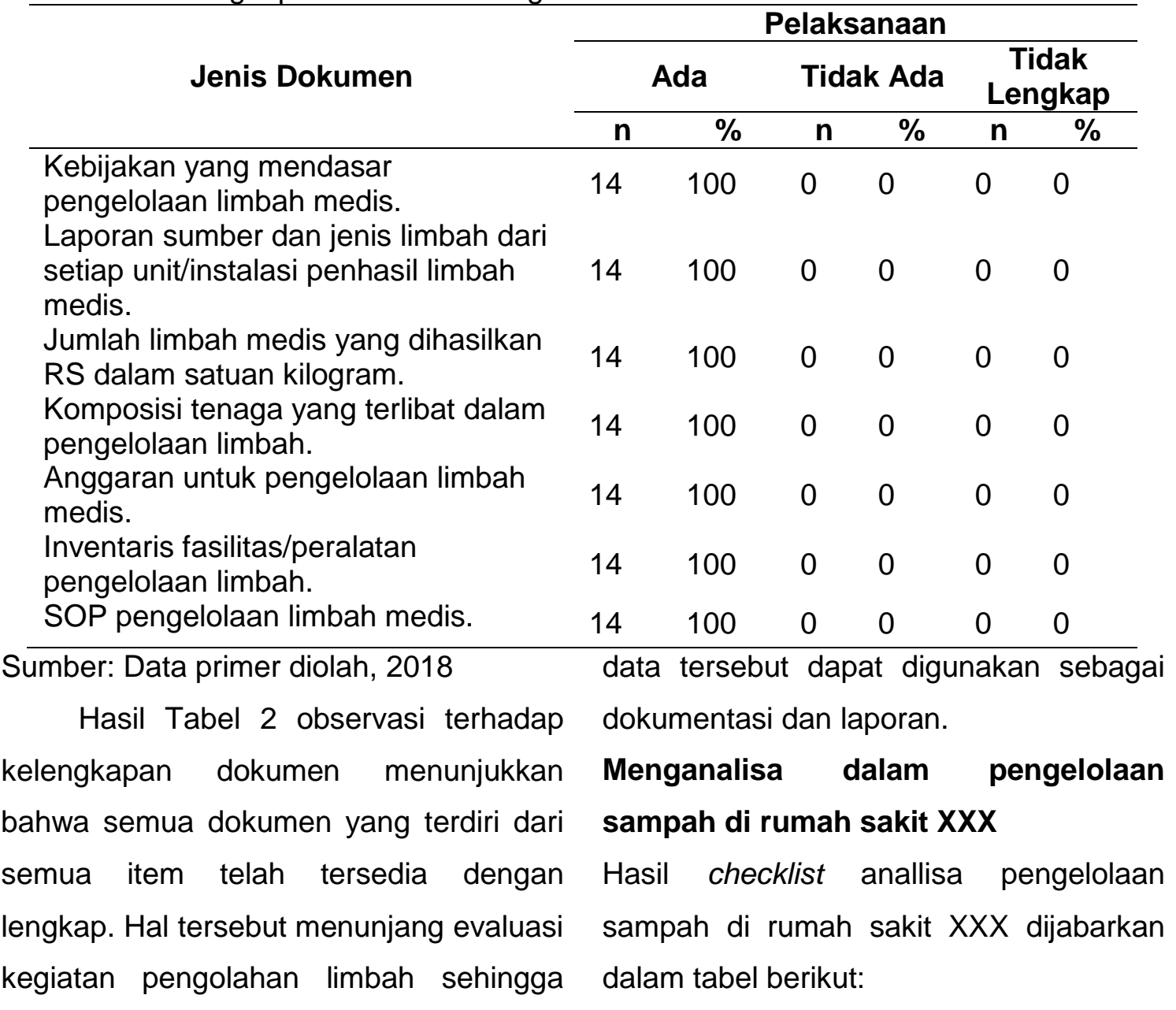


Tabel 3 Pengelolaan Sampah di Rumah Sakit XXX

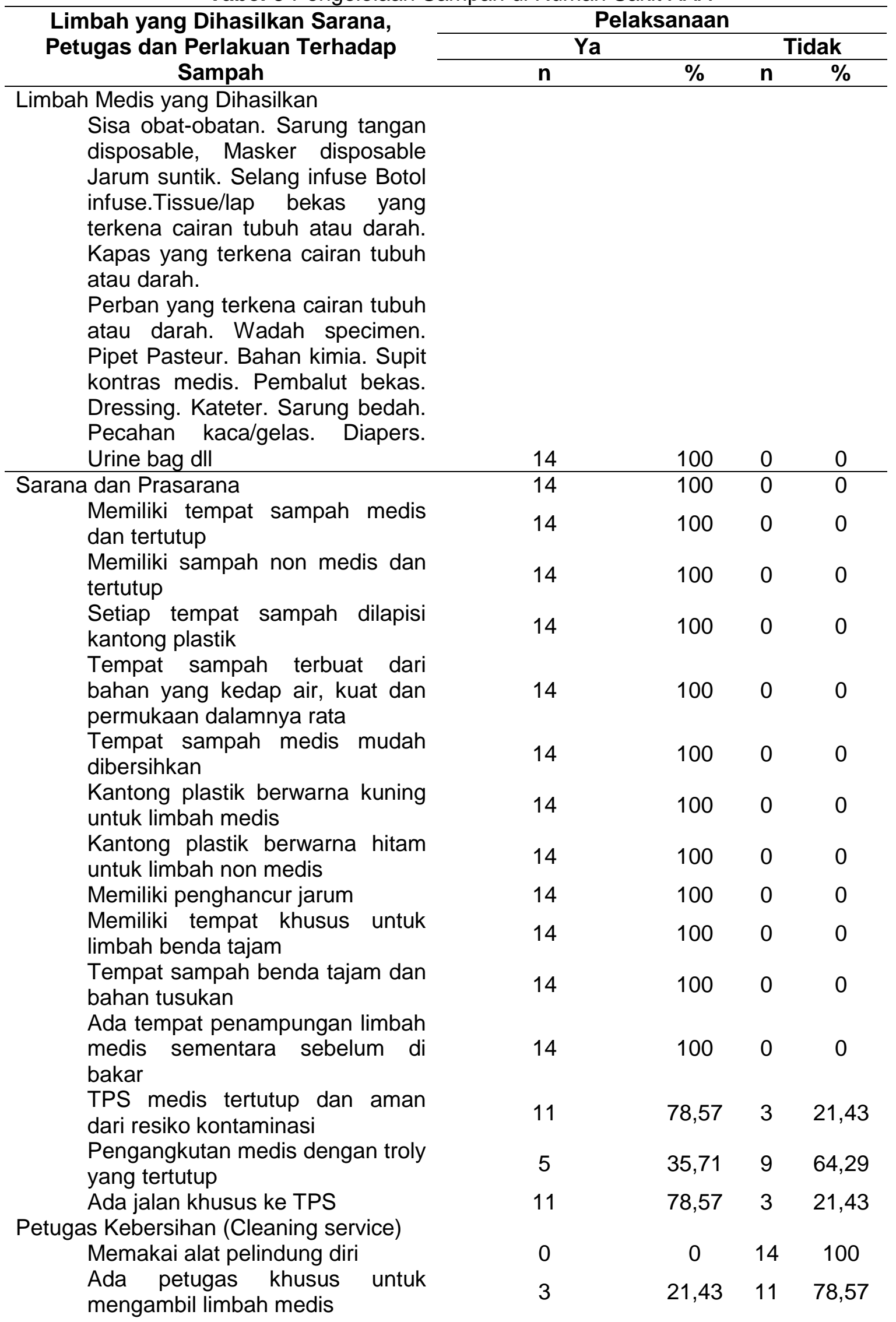




\begin{tabular}{|c|c|c|c|c|}
\hline \multirow{3}{*}{$\begin{array}{c}\text { Limbah yang Dihasilkan Sarana, } \\
\text { Petugas dan Perlakuan Terhadap } \\
\text { Sampah }\end{array}$} & \multicolumn{4}{|c|}{ Pelaksanaan } \\
\hline & \multicolumn{2}{|c|}{$\mathrm{Ya}$} & \multicolumn{2}{|c|}{ Tidak } \\
\hline & $\mathbf{n}$ & $\%$ & $\mathbf{n}$ & $\%$ \\
\hline $\begin{array}{l}\text { Ada petugas khusus untuk } \\
\text { mengambil limbah non medis }\end{array}$ & 14 & 100 & 0 & 0 \\
\hline \multicolumn{5}{|l|}{ Perlakuan Terhadap Limbah } \\
\hline $\begin{array}{l}\text { Limbah medis dan non medis } \\
\text { diambil setiap hari }\end{array}$ & 12 & 85,71 & 2 & 14,29 \\
\hline $\begin{array}{l}\text { Limbah medis diambil setiap pagi } \\
\text { dan sore }\end{array}$ & 2 & 14,29 & 12 & 85,71 \\
\hline $\begin{array}{l}\text { Limbah hanya diambil pada pagi } \\
\text { hari saja }\end{array}$ & 0 & 0 & 14 & 100 \\
\hline $\begin{array}{l}\text { Setiap tempat penuh meskipun } \\
\text { belum ada yang diambil plastik } \\
\text { tetap diikat }\end{array}$ & 0 & 0 & 14 & 100 \\
\hline Bila sampah tidak diambil, & & & & \\
\hline $\begin{array}{l}\text { sampah dibuang sendiri oleh } \\
\text { perawat ke TPS }\end{array}$ & 3 & 21,43 & 11 & 78,57 \\
\hline $\begin{array}{l}\text { Pemilihan limbah dilakukan oleh } \\
\text { petugas kesehatan (perawat) }\end{array}$ & 12 & 85,71 & 2 & 14,29 \\
\hline $\begin{array}{l}\text { Plastik limbah dianggap penuh } \\
\text { bila terisi } 3 / 4 \text { plastic }\end{array}$ & 13 & 92,86 & 1 & 7,14 \\
\hline $\begin{array}{l}\text { Plastik limbah hanya digunakan } \\
\text { satu kali dan langsung dibuang }\end{array}$ & 7 & 50,00 & 7 & 50,00 \\
\hline $\begin{array}{l}\text { Pemilahan terhadap limbah medis } \\
\text { dan non medis dilakukan dengan } \\
\text { benar }\end{array}$ & 9 & 64,29 & 5 & 35,71 \\
\hline $\begin{array}{l}\text { Masih ditemukan adanya limbah } \\
\text { medis dan non medis yang } \\
\text { tercampur di dalam tempat } \\
\text { sampah }\end{array}$ & 4 & 28,57 & 10 & 71,43 \\
\hline Sementara menunggu & & & & \\
\hline $\begin{array}{l}\text { pengangkutan, kantong plastik } \\
\text { kuning diikat dan diletakkan di } \\
\text { ruang khusus }\end{array}$ & 2 & 14,19 & 12 & 85,71 \\
\hline $\begin{array}{l}\text { Pembakaran dilakukan dengan } \\
\text { suhu } 1000^{\circ} \mathrm{C}\end{array}$ & 0 & 0 & 14 & 100 \\
\hline $\begin{array}{l}\text { Selama pengangkutan ada limbah } \\
\text { medis yang tercecer }\end{array}$ & 0 & 0 & 14 & 100 \\
\hline $\begin{array}{l}\text { Insenerator dilengkapi dengan } \\
\text { cerobong asap }\end{array}$ & 1 & 7,14 & 13 & 92,86 \\
\hline $\begin{array}{l}\text { Asap pembakaran berwarna } \\
\text { hitam }\end{array}$ & 4 & 28,57 & 10 & 71,43 \\
\hline $\begin{array}{ll}\text { Petugas } & \text { insenerator } \\
\text { menggunakan APD } & \end{array}$ & 0 & 0 & 14 & 100 \\
\hline Tanda-Tanda Peringatan & & & & \\
\hline $\begin{array}{l}\text { Ada peringatan, buanglah } \\
\text { sampah pada tempatnya }\end{array}$ & 13 & 92,86 & 1 & 7,14 \\
\hline $\begin{array}{l}\text { Ada peringatan limbah medis dan } \\
\text { non medis }\end{array}$ & 14 & 100 & 0 & 0 \\
\hline $\begin{array}{l}\text { Ada peringatan jagalah } \\
\text { kebersihan }\end{array}$ & 14 & 100 & 0 & 0 \\
\hline
\end{tabular}




\begin{tabular}{|c|c|c|c|c|}
\hline \multirow{3}{*}{$\begin{array}{c}\text { Limbah yang Dihasilkan Sarana, } \\
\text { Petugas dan Perlakuan Terhadap } \\
\text { Sampah }\end{array}$} & \multicolumn{4}{|c|}{ Pelaksanaan } \\
\hline & \multicolumn{2}{|c|}{ Ya } & \multicolumn{2}{|c|}{ Tidak } \\
\hline & $\mathbf{n}$ & $\%$ & $\mathbf{n}$ & $\%$ \\
\hline Ada peringatan lain ... & 14 & 100 & 0 & 0 \\
\hline $\begin{array}{l}\text { Ada SOP/petunjuk penanganan } \\
\text { limbah dari instalasi pengelolaan } \\
\text { limbah }\end{array}$ & 14 & 100 & 0 & 0 \\
\hline
\end{tabular}

Sumber: Data primer diolah, 2018

Observasi sarana dan fasilitas pada Tabel 3 yang ada dirumah sakit meliputi tepat sampah yang sesuai, kantong palastik warna, memiliki penghancur dan tempat benda tajam serta memiliki tempat penampungan limbah medis sementara sebelum dibakar sudah terlaksana semua. Namun, tidak semua unit bangsal menyediakan TPS yang tertutup atau aman dan ada jalan khusus ke TPS (78,57\%), selain itu, pengangkutan medis dengan troly yang tertutup juga diketahui belum terlaksana $(35,71 \%)$. Observasi petugas kebersihan dirumah sakit menunjukkan terdapat petugas khusus untuk mengambil limbah non medis dan tidak ada petugas khusus untuk mengambil limbah medis. Petugas diketahui memakai alat pelindung diri (sarung, masker, sepatu boot, wearpack) (78,57\%).

Observasi perlakuan terhadap limbah sebagian besar dilakukan, seperti limbah medis dan non medis diambil setiap hari $(85,71 \%)$, pemilihan limbah dilakukan oleh petugas kesehatan (perawat) $(85,71 \%)$, plastik limbah dianggap penuh bila terisi $3 / 4$ plastic $(92,86 \%)$, dan pemilahan terhadap limbah medis dan non medis dilakukan dengan benar (64,29\%). Sedangkan perlakuan yang mayoritas tidak dilakukan meliputi limbah medis diambil setiap pagi dan sore $(85,71 \%)$, bila sampah tidak diambil sampah dibuang sendiri oleh perawat ke tps $(78,57 \%)$, adanya limbah medis dan non medis yang tercampur di dalam tempat sampah $(71,43 \%)$, menunggu pengangkutan, kantong plastik kuning diikat dan diletakkan di ruang khusus $(85,71 \%)$, insenerator dilengkapi dengan cerobong asap (92,86\%) dan asap pembakaran berwarna hitam (71,43\%). Sedangkan pengelolaan perlakuan limbah lainnya tidak dilakukan semua.

Observasi fasilitas berdasarkan tanda-tanda peringatan diketahui tersedia semua, hanya peringatan buang sampah pada tempatnya yang belum tersedia secara lengkap (92,86\%).

\section{Pembahasan}

\section{Pelaksanaan Prosedur Pengolahan} Limbah di Rumah Sakit XXX

Pada tahap pemilahan diketahui bahwa nomor 1 dan 2 sudah dilakukan namun pada nomor 3 tidak dilakukan. Hal yang sudah dilakukan sesuai dengan 
prosedur pada pernyataan pemilahan limbah medis harus dilakukan mulai dari sumber yang menghasilkan limbah, serta pernyataan jarum dan syringes harus dipisahkan agar tidak dapat digunakan kembali.

Pada tahap pewadahan dan pemanfaatan kembali atau daur ulang pada nomor 4-10 menunjukkan semua kegiatan dilaksanakan. Limbah medis benda tajam harus dikumpulkan dalam satu wadah. Wadah yang digunakan harus sesuai standar operasional yaitu wadah yang anti bocor, anti tusuk dan tidak mudah dibuka.

Pada tahap pengumpulan, pengangkutan, dan penyimpanan limbah medis benda tajam sebagian besar sudah dilakukan. Pengumpulan dan pengangkutan sudah dilaksanakan dengan baik yaitu meliputi kantong harus tertutup apabila sudah penuh $3 / 4$, limbah dimasukkan dalam container serta pengangkutan kantong limbah dilakukan setiap hari dan diangkut menggunakan troli. Untuk memudahkan proses pengumpulan, maka pengosongan dan pengangkutan limbah pada tempat sampah, penggunaan kantong plastik sesuai jenis limbah sangat disarankan karena membantu menampung limbah saat pengangkutan.

Observasi yang dilakukan diketahui bahwa alat angkut memiliki sudut tajam dan petugas tidak melakukan alat pelindung diri. Sesuai dengan ketentuan yang berlaku petugas yang menangani limbah, harus menggunakan alat pelindung diri yang terdiri: Topi/helm, Masker, Pelindung mata, Pakaian panjang, Apron untuk industry, Pelindung kaki/sepatu boot, dan Sarung tangan kusus. Hal tersebut menunjukkan bahwa kedisiplinan SDM terutama petugas sanitasi masih perlu ditingkatkan.

Penyimpanan limbah pada musim hujan tidak dilakukan petugas maksimal 48 jam dan musim kemarau 24 jam. Artinya, petugas melakukan pembuangan lebih dari 48 jam pada musim hujan dan lebih dari 24 jam pada musim kemarau. Limbah padat medis yang mengandung berbagai jenis penyakit, virus dan bakteri sangat berbahaya bagi lingkungan sekitar apabila tidak dilakukan tindakan untuk melakukan pengambilan sampah medis secara teratur dan tepat pada waktunya.

Hasil observasi pada tahap pengolahan dan pemusnahan limbah medis benda tajam diketahui bahwa nomor 17, 18 dan 19 sudah dilakukan, tetapi pada nomor 20 kegiatan tidak dilakukan (85,71\%). Hal tersebut menunjukkan dalam pengolahan dan pemusnahan limbah sesuai dengan prosedur seperti ditambah berdasarkan jenisnya, dilakukan dokumentasi dan pencatatan limbah medis serta pemusnahan dengan incinerator dengan suhu $700^{\circ} \mathrm{C}$. 
Tahapan selanjutnya yaitu pembuangan akhir limbah medis benda tajam pada nomor 21 dan 22 tidak dilakukan semua. Kegiatan pembuangan akhir tidak dilakukan oleh pihak rumah sakit dikarenakan menggunakan pihak ketiga yang berizin. Setiap RS memiliki metode dan cara pembuangan akhir limbah pilahan yang sama.

Sedangkan tahap dan syarat pencatatan dan pelaporan pada nomor 23 sudah dilakukan $(85,71 \%)$ dan nomor 24 , 25 dan 26 sudah dilakukan semua. Hal ini sesuai dengan peraturan Menteri Kesehatan dan Pemerintah Daerah yang menyatakan bahwa setiap penanggung jawab usaha atau kegiatan yang membuang air limbah wajib melakukan pencatatan debit harian air limbah, melakukan pencatatan $\mathrm{pH}$ harian air limbah dan memeriksakan kadar parameter air limbah secara berkala (7).

Kelengkapan Dokumen Pengolahan Limbah di Rumah Sakit XXX

Hasil observasi terhadap

kelengkapan dokumen menunjukkan

bahwa semua dokumen pengelolaan

limbah medis ada dan lengkap. Hal tersebut dapat digunakan sebagai evaluasi kegiatan pengolahan limbah untuk dokumentasi dan laporan.

Sirait (2016) menyatakan bahwa pengelolaan lingkungan rumah sakit yang baik diperkirakan akan memberikan pelayanan yang baik pula. Kelengkapan dokumen Pengelolaan Sampah Medis dapat memberikan peningkatan pelayanan (8). di rumah sakit XXX. Untuk itu diharapkan rumah sakit XXX dapat mempertahankan dan terus memperbaiki dokumen pengelolaan limbah medis sehingga dapat dijadikan sebagai acuan dalam pelaksanaan pengolahan limbah.

\section{Menganalisa dalam Pengelolaan}

\section{Sampah di rumah sakit $X X X$}

rumah sakit $X X X$ menunjukkan terdapat beberapa limbah medis yang dihasilkan meliputi sisa obat-obatan, sarung tangan disposable, masker disposable, jarum suntik, selang infus, botol infus, tissue atau lap, kapas, perban, wadah specimen, pipet Pasteur, bahan kimia, supit kontas medis, pembalut bekas, dressing, kateter, sarung bedah, pecahan gelas, diapers dan urine bag.

Observasi sarana dan fasilitas yang ada dirumah sakit sudah tersedia. Namun masih terdapat fasilitas yang perlu ditingkatkan dari ketersediaan fasilitas yang layak dan memadai seperti TPS yang selalu tertutup serta pengangkutan troli yang tertutup. Selain itu tidak ada jalan khusus menuju TPS.

Observasi petugas kebersihan dirumah sakit menunjukkan terdapat petugas khusus untuk mengambil limbah non medis dan petugas memakai alat pelindung diri (sarung, masker, sepatu boot, wearpack) (78,57\%). Selain itu, 
tidak ada petugas khusus untuk limbah medis yang tercecer dan petugas mengambil limbah medis. Menurut insenerator menggunakan APD (100\%). Kementrian Lingkungan Hidup (2006) Pengelolaan perlakuan limbah yang tidak limbah medis terdiri atas $11 \%$ limbah dilakukan merupakan hal-hal yang perlu infeksius dan 4\% limbah berbahaya. diperhatikan untuk diadakan pengasawan Selama ini penanganan limbah medis dan evaluasi karena dapat menyebarkan ditangani oleh petugas umum.

penyakit bagi para pekerja yang

Observasi perlakuan terhadap mengelola sampah rumah sakit.

limbah sebagian besar sudah dilakukan oleh pihak rumah sakit seperti Fasilitas berdasarkan tanda-tanda peringatan diketahui ada semua. pengambilan limbah setiap hari $(85,71 \%)$, perawat melakukan pemilahan limbah (85,71\%), limbah plastik dianggap penuh bila terisi $3 / 4$ (92,86\%), dan pemilahan limbah medis dan non medis dilakukan dengan benar (64,29\%). Sedangkan perlakuan mayoritas yang tidak dilakukan meliputi pengambilan limbah pagi dan sore $(85,71 \%)$, sampah dibuang sendiri oleh perawat $(78,57 \%)$, limbah medis dan non medis di tempat sampah $(71,43 \%)$, kantong kuning diikat dan diletakkan di ruang khusus $(85,71 \%)$, insenerator dilengkapi pada cerobong asap (92,86\%) dan asap pembakaran berwarna hitam $(71,43 \%)$. Masih adanya petugas yang belum menggunakan perlakuan sesuai dengan syarat yang ada.

Sedangkan pengelolaan pada perlakuan limbah yang tidak dilakukan meliputi limbah diambil pada pagi hari saja, setiap tempat penuh meskipun belum ada yang diambil plastik tetap diikat, pembakaran dilakukan dengan suhu $1000 \mathrm{C}$, selama pengangkutan ada Terdapat satu fasilitas yang tidak ada yaitu peringatan buang sampah pada tempatnya $(92,86 \%)$, sehingga peringatan buang sampah pada tempatnya perlu diperbanyak dan dilengkapi lagi.

\section{SIMPULAN DAN SARAN}

\section{Simpulan}

Pelaksanaan prosedur pengolahan limbah B3 di rumah sakit XXX belum sesuai dengan ketentuan kriteria Kepmenkes RI Nomor 1204 Tahun 2004 tentang Persyaratan Kesehatan Lingkungan Rumah Sakit dan kriteria PP Nomor 101 Tahun 2014 tentang Pengelolaan Limbah Bahan Berbahaya dan Beracun (B3). Kelengkapan dokumen pengolahan limbah di rumah sakit $X X X$ yang terdiri dari kebijakan yang mendasar pengelolaan limbah medis, laporan sumber dan jenis limbah dari setiap unit atau instalasi penhasil limbah medis, jumlah limbah medis yang dihasilkan RS dalam satuan kilogram, komposisi tenaga yang terlibat dalam pengelolaan limbah, anggaran untuk pengelolaan limbah 
medis, inventaris fasilitas atau peralatan pengelolaan limbah dan SOP pengelolaan limbah medis ada dan sudah tersedia dengan lengkap. Pengelolaan sampah di rumah sakit $\mathrm{XXX}$ belum sesuai dengan kriteria UU no 32 tahun 2009 tentang perlindungan dan pengelolaan sampah

\section{Saran}

Diharapkan rumah sakit XXX mengelola sampah dan prosedur pengolahan limbah B3 sesuai dengan kriteria UU no 32 tahun 2009 tentang perlindungan dan pengelolaan sampah dan ketentuan Kepmenkes RI Nomor 1204 Tahun 2004 tentang Persyaratan Kesehatan Lingkungan Rumah Sakit dan kriteria PP Nomor 101 Tahun 2014 tentang Pengelolaan Limbah Bahan Berbahaya dan Beracun (B3).

DAFTAR PUSTAKA

1. Indonesia MKR. Peraturan Menteri Kesehatan Republik Indonesia Nomor: 1045/MENKES/PER/XI/2006 Tentang Pedoman Organisasi Rumah Sakit Di Lingkungan Departemen Kesehatan. 2006;

2. Indonesia R. Undang-undang nomor 32 tahun 2009 tentang perlindungan dan pengelolaan Sampah. 2009;
3. Arifin M. Pengaruh Limbah Rumah Sakit Terhadap Kesehatan. Depok: FKUI; 2008.

4. Menteri Kesehatan Republik Indonesia. Keputusan Menteri Kesehatan Nomor: 1204/MENKES/SK/X/2004 tentang Persyaratan Kesehatan Lingkungan Rumah Sakit. Jakarta: Departemen Kesehatan; 2004.

5. Nugroho S, Trihadiningrum Y. Kajian pengelolaan sampah medis pada RSUD dr. Soedono Madiun. Prosiding Seminar Nasional Manajemen Teknologi V. Surabaya: Program Studi MMT-ITS; 2007.

6. Machfoedz I. Metodologi Penelitian (Kuantitatif \& Kualitatif). Revisi. Yogyakarta; 2016.

7. Sari DR. Evaluasi Pengolahan Air Limbah dengan Sistem Extended Aeration di Rumah Sakit "X" Semarang (Doctoral dissertation, Universitas Negeri Semarang). 2015;

8. Sirait AAFD, Mulyadi A, Nazriati E. Analisis Pengelolaan Limbah Medis Di Rumah Sakit Umum Daerah (RSUD) Gunungtua Kabupaten Padang Lawas Utara Propinsi Sumatera Utara. J Ilmu Lingkung. 2016;9(2):183-92. 